\title{
リスク・ベネフィットコミュニケーション：海外の動向と今後の展望
}

\author{
山本美智子
}

\section{Risk/Benefit Communication: International Developments and Prospects for the Future}

\author{
Michiko Yamamoto \\ Department of Drug Informatics, Center for Education \& Research on Clinical Pharmacy, Showa \\ Pharmaceutical University; 3-3165 Higashi-Tamagawagakuen, Machida, Tokyo 194-8543, Japan.
}

(Received August 4, 2017)

\begin{abstract}
While expectations for the benefits of pharmaceuticals are high, the occurrence of health damage from adverse drug reactions remains a problem. One of the reasons for this seems to be insufficient risk communication among stakeholders. Healthcare professionals (HCPs), relevant agencies, and pharmaceutical companies have responsibilities to communicate useful information on the risks/benefits of the pharmaceuticals they provide in addition to basic policies and services. Four years have passed since the risk management plan system was introduced in Japan. Although relevant materials for patients and HCPs are offered, it is still difficult to determine whether they are being utilized effectively. The provision of drug information to patients is necessary to allow them to take medicine safely, while maximizing the benefits and minimizing the risks associated with pharmacotherapy. By incorporating survey results on patients' level of understanding of drug risks/benefits, a system to provide information emphasizing the perspectives of patients has been promoted in Europe and North America. In the study of safety issues on a scientific basis, risk communication will become an increasingly important subject. This is a field to which pharmacologists and pharmacists can contribute during this symposium. This paper introduces research activities on risk communication that have been carried out in Japan as well as internationally.
\end{abstract}

Key words_— risk/benefit communication; usability; understandability; readability; user testing; communication index

\section{1.はじめに}

医薬品のベネフィットの期待が大きい一方で，副 作用による健康被害も後を絶たない. 要因の 1 つと して, リスク・ベネフィットに関するコミュニケー ションが十分に行われていないことが考えられる.

医療従事者, 組織や企業は, 提供する医薬品のリス ク・ベネフィット及びポリシーやサービスに関する 有用な情報を提供する責任がある.

しかし，Fischoff らによると，ヒューリスティッ クな決定ルールとして，人が一度に扱える情報量は わずかであり，一度に考えることができる心理学的 上限值は $7 \pm 2$ 項目程度であるとしている. 1) 情報の 送り手は，自分の考えが一般常識と考えてしまう傾 向があり，説明不足の傾向にある。 また，送り手は

昭和薬科大学臨床薬学教育研究センター医薬品情報部 門（干194-8543 東京都町田市東玉川学園 3-3165） e-mail: m-yamamoto@ac.shoyaku.ac.jp 本総説は, 日本薬学会第 137 年会シンポジウムS29 で 発表した内容を中心に記述したものである.
受け手が送り手の意図をくみとつてくれると過剰に 期待する傾向にあることも指摘している.

リスク管理計画がスタートして早 4 年，それに関 連した医療従事者及び患者向け資材も提供されてい るが，まだ十分に活用されているとは言い難い。患 者向けの医薬品情報は, 患者が医薬品を安全に服用 し，医薬品から得られるべネフィットの最大化とリ スクの最小化のために必要である. また, 患者向け の情報提供文書では，患者が必要な情報をすぐに見 い出せること, 患者が必要な行動を想起できるよう な明確な説明が求められる。

欧米では患者関与による理解度調査を取り入れた 上で，患者の視点を重視した情報提供のエビデンス に基づいた取り組みが推進されている，わが国のリ スクコミュニケーション研究は，残念ながら欧米各 国に比べまだ十分とは言えない状況である。今回, 米国を中心とした海外の医薬品に関するリスクコ ミュニケーション状況を概説する. 
2.リスク・ベネフィットコミュニケーションに ついて

2-1. 科学コミュニケーションの経緯と背景 リスクコミュニケーションに大きく関係している 要因に，科学技術の発達がある，そのため，一般の 人と専門家の間での科学に対する理解のギャップは 広がっていった。一般市民の多くに科学リテラシー が不足しているという危機感が生まれ，このことは 両者間で様々な軋轁を生むことになった。一般の人 に対する科学の理解の改善に向け, 1980 年代頃か ら啓発活動が展開されるようになり，このような活 動は, The public understanding of science (PUS) と呼ばれた。英国王立協会は，1985 年にPublic Understanding of Science と題する報告書を出し, 人々の科学に対する理解の必要性と改善のための施 策を提案した. ${ }^{2)}$ また，90 年代後半からは，一般の 人は専門家の考え方を受け入れるべきであるという public acceptance (PA) という考え方も出てきた. 1997 年には, 経済協力開発機構 (Organisation for Economic Co-operation and Development; OECD) が Promoting Public Understanding of Science and Technology を発表し，それは 2001 年に更新されて いる.3)この報告書には次のような記載がある.

「PUS は，科学や技術に関する最新の知識を得るこ とが目的ではなく，情報を批判的に読み取り，さら には公衆に対し意思決定へ影響を与える営みとして 捉えられるべきである」。このような情報を提供し た上での意思決定（Informed Decision）に至るこ とが，コミュニケーションの原点であると考えられ る. 特に, 医療の場においては，患者・医療従事者 が必要な情報を共有したうえでの意思決定（シェ アード・ディシジョン・メイキング : Shared Decision Making）が求められる。先患者・医療従事者の 双方が，パートナーシップに基づきお互いの専門性 を尊重したうえで，意思決定のために話し合うプロ セスが重要である。 また，シェアード・ディシジョ ン・メイキングやコンコーダンス (Concordance) の権利のみではなくそれに加え，近年では，国民も 努力し責任を負うという責務の共有（Shared Responsibility）という考え方も重要視されている. この現れとして, 医薬品, 医療機器等の品質, 有効 性及び安全性の確保等に関する法律第一条の六にも 国民の役割として，次の記載がある。「国民は，医
薬品等を適正に使用するとともに，これらの有効性 及び安全性に関する知識と理解を深めるよう努めな ければならない」。このように，今後は医療従事者 と患者・専門家と国民間で Shared Decision Making とともに，Shared Responsibility の考え方が注目さ れ普及していくと考えられる。

2-2. リスクコミュニケーションの発達近 年，よく用いられるようになつた言葉として，市民 の意識, 参加, 対話があり, コミュニケーションの あり方が．消費者・患者における理解，参加から関 与 (engagement) へと転換してきている.

リスクコミュニケーションの発達のプロセスを見 ていこう. 大きく分けて次の 3 つのステップが考え られる。.まず，第一のステップでは「データの開示」 である.ここでは，データは開示されるが，専門的 な内容のままでよく理解されない状況である。これ は一方向の提供であり，相互作用的なファクターは ない，第二のステップでは，「情報の提供」を積極 的に行うようになるが，教育，宣伝，解説，説得手 法に関心が置かれ，都合のよい点を強調する場合も みられる。第三のステップでは，「共通ベースと意 見交換」に至り，情報の提供者と消費者・患者など の利用者が情報を共有し，お互いに意思疎通を図り 相手の意見を聞き討議するとされる。この段階に至 り，情報内容に留まらず，コミュニケーションのあ り方を重視するといつたことが挙げられる.この第 三段階に到達して，初めてリスクコミュニケーショ ンに求められているレベルに達したと考えられ る. ${ }^{5,6)}$

2-3. リスクコミュニケーションとはリスク コミュニケーションは，リスク評価の内容などに関 して，最終的には関係者間で情報や意見をお互いに 交換し，合意形成を図ろうとするものである.リス クについて，それが一体「どんなリスクなのか」， 「どの程度のリスクなのか」，「それにどう対応する のか」について社会に伝えることが必須である.

医薬品の場合，リスクの定義は，WHO Uppsala Monitoring Centre (UMC) によると「ある事象が 発生する確率 (The probability of developing an outcome)」を(う.7)ただし，リスクは一般的にはネ ガティブなアウトカムに常に言及される訳ではな く，また，ハーム（害）の対比として，アウトカム の重篤度に係わるものではない。リスクコミュニ 
ケーションの定義は，「一般的にはリスクに関する 情報を専門家内に留めず，一般公衆を含む利害関係 者間において共有し，消費者が健康や安全性等のリ スクに関し独立した判断ができるように意図された コミュニケーション」とされている. ${ }^{8)}$ また， WHO UMC から, 1997 年に, 医薬品の安全性監視 における効果的なコミュニケーションに向けたエリ 又宣言（Erice Declaration）が出され，その規範理 念として次のことが提示された. ${ }^{9}$

・リスクとベネフィットを評価し理解するため にすべてのエビデンスは利用されるよう公開するこ と.

・ 目的を達成するための関係者間のコミュニ ケーションを阻害するものを認識し，克服するこ と.さらに，社会に向けたリスクコミュニケーショ ンと個別の患者のためのリスクコミュニケーション, これら 2 つレレベルのリスクコミュニケーションを 達成することが求められた。

リスクコミュニケーションの目的は，まず第一 に，安全性情報の伝達，そして利害関係者の意見交 換，さらに相互理解の促進，最終的に責務の共有が ある。リスク・ベネフィットコミュニケーションを 行う上での基本方針として，以下のことが挙げられ る.

- 情報の透明化

- 情報の共有化・双方向性

・ エビデンスに基づいた情報の提供

- 患者参画

まず，情報提供において，その公開性や透明性が 担保されることが前提となる，それは，エビデンス に基づいた情報でかつ費用対効果の情報も望まれ る。また，情報の共有化は，利害関係者間で行われ るべきで，患者の積極的な関与も求められる.

3. 米国におけるリスクコミュニケーションの取 り組み

米国の医療に関するリスクコミュニケーションに ついて，2つの大きな流れから見ていくことができ る。1つは，医薬品の安全性問題に端を発した Food and Drug Administration（FDA）の改革であ る。も も 1 つは英語の平易言語運動である。この 2 つの流れにより，科学的な視点によりリスクコミュ ニケーションを分析し，より戦略的なリスクコミュ ニケーションの取り組みになっていると思われる.
3-1. FDA 改革におけるリスクコミュニケー ション 米国では, cyclooxygenase (COX)-2 阻 害剤である rofecoxib $\left(\operatorname{Vioxx}^{\circledR}\right)$ による心血管系の 副作用が問題となり，同医薬品は 2004 年に販売中 止となった. その他, 抗うつ薬 parecoxib $\left(\mathrm{Paxil}^{\circledR}\right)$, 経口糖尿病薬 rosiglitazone（Avandia ${ }^{\circledR}$ ) などによる 被害も重なり，FDA は，国民の健康を本当に守る ことができるのかといった安全性に関する重い課題 が突き付けられた．FDAの要請を受けて，米国医 学研究所 (Institute of Medicine; IOM) は医薬品の 安全性に関し FDA の改革策を提言し，2007 年に 「FDA 改革法」が成立した。2009 年には，FDA’s Strategic Plan for Risk Communication（リスクコミ ユニケーション戦略計画）が公表された。 ${ }^{6}$ この文 書では，科学，能力及び政策の 3 つの主要な領域を 定めており，国内外の利害関係者と協力して行い,

リスクコミュニケーションの作成，普及及び規制を 改善するものである．概略を以下に示すように，リ スクコミュニケーションの科学的な対策や検証に重 きを置いていると言える. ${ }^{10,11)}$

1）効果的なリスクコミュニケーションを支援す る科学の強化

科学戦略として

- リスクコミュニケーションの知識と実行に関 する主要領域における隔たり，及び隔たりを埋める ための作業を決定する.

- FDAのリスクコミュニケーションの効果と 関連活動を評価し，他の利害関係者の活動を監視す る.

・ 調査・評価を通じて得られた知識を実用化に 向けて解釈し，統合する.

2）効果的なリスクコミュニケーションの作成, 普及及び監視のための FDA の能力拡大

能力戦略として

・ コミュニケーションメッセージ及び活動の開 発を合理化し, 効果的に連携する.

・ クライシスコミュニケーションのための計画 を立案する。

・評価を含めたコミュニケーション研究及びテ スト実施プロセスを効率化する.

- 草案の作成，検討，テスト実施，わかり易い メッセージの作成に係わる職員の役割と責任を明確 化する. 
- 意思決定及び行動科学の専門性を備えた職員 を増員し，その職員をコミュニケーションの企画立 案及びメッセージの作成に関与させる.

・ 様々な利害関係者とコミュニケーションを行 うための基本的な仕組みとして，FDA のウェブサ イトとウェブツールの実効性を改善する.

- 政府組織及び非政府組織との提携の強化を通 して，双方向のコミュニケーションを推進する.

3）リスク・ベネフィットのコミュニケーション に関する FDA 政策の最適化

政策戦略として

・ FDA のコミュニケーションが一貫性を持ち 理解され易い方針を立てる.

・ 新たなリスク発生情報をいつ，どのような方 法で提供するかについて一貫性のある基準を決定す る.

・ 規制製品に関する有効なコミュニケーション の推進に向け，パートナーと協働するための政策を 再評価し最適化する。

- 公衆の健康に与える影響が大きい領域におけ る FDA コミュニケーション政策を評価し改善する.

2011 年には，FDA リスクコミュニケーション諮 問委員会のメンバーより，Communicationg Risks and Benefits: An Evidence-Based User's Guide (FDA リスク\&ベネフィット・コミュニケーション エビデンスに基づく健康・医療に関する指針）が公 表され，エビデンスに基づく提言がなされた. ${ }^{12)}$ 2012 年には，ガイダンスとして, Drug Safety Information-FDA's Communication to the Public（医 薬品の安全性情報一公衆へ向けた FDA のコミュニ ケーション）が出され，国民が医療において医療従 事者と患者が治療の決定を行う際に医薬品の最新の 安全性情報が利用可能とすることを目指した。つま り，医薬品の安全性問題を契機に，FDA は実効性 のあるリスクコミュニケーション対策を取ってきて いる.このように，医薬品の安全性の課題に対する リスクコミュニケーションの重要性からその対策や 取り組みが行われてきた。

3-2. 米国における平易な言語運動 リスクコ ミュニケーションを語る上で，米国における平易な 言語運動は，行政機関の文書等にとつて重要な位置 づけとなる. 1970 年代のニクソン大統領政権時代 に，連邦官報を一般市民にもわかるような平易な英
語で記載するよう政令が出されたことに端を発す る。その後，クリントン大統領は，平易な言語を 使って政府と国民との間のコミュニケーションを円 滑にするため，連邦政府機関に対し，1998 年に， 大統領覚書 (Presidential Memorandum) ${ }^{13)}$ を発令 した。 2010 年に，オバマ大統領は，The Plain Writing Act of 2010 (平易記載法 2010 年）に署名し

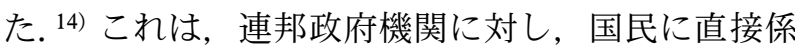
わる内容の情報や通知は，平易言語を用いて国民が 理解できる簡潔で明瞭なものにすることを義務付け る法律である．平易記載法の制定後，今日に至るま で，多くの行政機関では，国民と明瞭なコミュニ ケーションを図ることを戦略の一部と位置付けてい る.

平易な言語による文書は，その対象となる読者に よって要求される内容は異なるが，一般的には，以 下の点などを考慮に入れるように指示されている.

・ 論理的に整理されており，読み易いデザイン である。一文を短くする。

・ 専門用語は最小限に抑え，日常使用される言 葉，語彙を使用する.

・ 能動態を使用する.

米国のいくつかの公的機関から患者向け資材の有 用性向上のための指針が出されている。例えば, National Cancer Institute（NCI）からは Making Health Communication Programs Work (Pink Book) , ${ }^{15)}$ National Institutes of Health (NIH) から は Clear Communication Clear \& Simple, ${ }^{16)}$ Centers for Disease Control and Prevention (CDC) からは Clear Communication Index (CCI) ${ }^{17)}$ が出されてい る.

CCI は平易記載法に準じ, National Action Plan to Improve Health Literacy 及び CDC Action Plan to Improve Health Literacy に記載されているゴールの 達成を支援するものとしている，また，対象者や目 的などを考慮し，患者向け資料の評価をスコア化し ており，使用が簡便である．小学 6 年生の読解レべ ルでのキーメッセージの作成を推奨している，CCI は 4 つのパート(コア, 行動の推奨, 数值, リスク), 20 の項目からなり，Yes/No で答える形式になって いる。これらの項目は Federal Plain Language Guidelines を踏襲しており，9割以上該当した場合 を適合と評価する（Table 1)。CDC では適合にな 
Table 1. CDC Clear Communication Index Score Sheet

\begin{tabular}{|c|c|c|c|}
\hline & & Questions & $\begin{array}{l}\text { Score } \\
(\mathrm{Yes}=1, \\
\text { No }=0)\end{array}$ \\
\hline $\begin{array}{l}\text { Part A: Core } \\
\text { The items in tl }\end{array}$ & is se & tion (1-11) apply to all materials. & \\
\hline & 1 & Does the material contain one main message statement? & \\
\hline & 2 & Is the main message at the top, beginning, or front of the material? & \\
\hline and Call to & 3 & Is the main message emphasized with visual cues? & \\
\hline & 4 & Does the material contain at least one visual that conveys or supports the main message? & \\
\hline & 5 & Does the material include one or more calls to action for the primary audience? & \\
\hline I & 6 & Do both the main message and the call to action use the active voice? & \\
\hline & 7 & Does the material always use words the primary audience uses? & \\
\hline & 8 & Does the material use bulleted or numbered lists? & \\
\hline Information & 9 & Is the material organized in chunks with headings? & \\
\hline & 10 & $\begin{array}{l}\text { Is the most important information the primary audience needs summarized in the first paragraph or } \\
\text { section? }\end{array}$ & \\
\hline $\begin{array}{l}\text { State of the } \\
\text { Science }\end{array}$ & 11 & $\begin{array}{l}\text { Does the material explain what authoritative sources, such as subject matter experts and agency } \\
\text { spokespersons, know and don't know about the topic? }\end{array}$ & \\
\hline Part A score & & & tal $\_/ 11$ \\
\hline Part B: Behav & oral & Recommendations & \\
\hline & 12 & Does the material include one or more behavioral recommendations for the primary audience? & \\
\hline & 13 & $\begin{array}{l}\text { Does the material explain why the behavioral recommendation (s) isimportant to the primary } \\
\text { audience? }\end{array}$ & \\
\hline & 14 & $\begin{array}{l}\text { Does the behavioral recommendation (s) include specific directions about how to perform the } \\
\text { behavior? }\end{array}$ & \\
\hline Part B score & & & otal __/3 \\
\hline Part C: Numb & & & \\
\hline & 15 & Does the material always present numbers the primary audience uses? & \\
\hline & 16 & Does the material always explain what the numbers mean? & \\
\hline & 17 & Does the audience have to conduct mathematical calculations? & \\
\hline Part C score & & & otal $\_/ 3$ \\
\hline Part D: Risk & & & \\
\hline & 18 & Does the material explain the nature of the risk? & \\
\hline & 19 & Does the material address both the risks and benefits of the recommended behaviors? & \\
\hline & 20 & $\begin{array}{l}\text { If the material uses numeric probability to describe risk, is theprobability also explained with words } \\
\text { or a visual? }\end{array}$ & \\
\hline
\end{tabular}

Part D score

Total $/ 3$

The Index has a total of 20 items in 4 parts. These 20 items are presented as questions.

- Questions 1-11 in Part A apply to all materials.

- Questions 12-20 in Parts B, C, and D may not apply to all materials.

- Choose one answer for each item you score (yes or no).

- Only score a point when all instances of an item in the material meet the criteria.

https://www.cdc.gov/ccindex/pdf/full-index-score-sheet.pdf 
るまで作成し直して公表する。その評価の手助けと なる Clear Communication Index User Guide も用意 されている，作成する際に，クイックチェックとし て，対象者について以下のことをまず検討するよう 促している.

（1）意図する対象者を特定したか?

(2) 対象者に関してリサーチを実施したか?

（3）行動目標とキーメッセージを特定したか?

（4）対象者に確実に届くために，資材がごのよ うに構成され配布されるかを決定したか?

（5）意図した対象者での資材のプレテスト及び フィードバックに基づく見直しのための時間や資 源を設定したか？

4. リスクコミュニケーションを効果的に行うた めに

リスクコミュニケーションツールの有用性（Usability）を科学的に評価する上で，重要視されてい るのは次の 3 項目である.

- 理解度 (Understandability)

- 入手し易さ (Accessibility)

- 可読性 (Readability)

この 3 項目はコミュニケーション資材について, 消費者・患者が，その内容を理解できるのか，必要 な情報をすぐに見つけ出すことができるのか，ま た，その情報が読み易いかといったことである。こ の資材内容の理解度や入手し易さを計る方法に, ユーザーテストがある。その他，文章の読み易さを 計る可読性の指標も，コミュニケーション資材の評 価に用いられる。

4-1. ユーザーテストユーザーテストは，情 報資材の有用性を客観的に評価する上で，小冊子や リーフレットからウェブ情報に至るまで消費者の健 康情報の改善に用いられる。ユーザーテストは実際 の生活にできるだけ近い状況で実施されることが望 ましい，情報資材について，特定の箇所を見い出す ために質問を設定し，参加者がそれを速やかに見い 出すことができたか，それを理解できているかを観 察する. ユーザーテストのもう 1 つの大きな目的と して, 患者の安全性確保があり, 重要な安全性メッ セージをいかに組み入れるかといったことも検証さ れる. European Union（EU）では，患者向けの医 薬品添付文書（Package Leaflet; PL）は医薬品の承 認要件の 1 つであるが，その際，一般の人や患者を
Table 2. The New Dale-Chall Formula and Drug Information Leaflets for Patients

\begin{tabular}{|c|c|c|c|}
\hline $\begin{array}{l}\text { Adjusted } \\
\text { Score }\end{array}$ & $\begin{array}{l}\text { Corresponding } \\
\text { Grade Level } \\
\text { (USA) }\end{array}$ & $\begin{array}{l}\text { Reference: } \\
\text { Corresponding } \\
\text { Grade Level } \\
\text { (Japan) }{ }^{a}\end{array}$ & $\begin{array}{l}\text { Official Drug } \\
\text { Information } \\
\text { Leaflets for } \\
\text { Patients }\end{array}$ \\
\hline 4.9 or lower & $\begin{array}{l}\text { Grade } 4 \text { and } \\
\text { lower }\end{array}$ & $\begin{array}{l}\text { Grade } 4 \text { and } \\
\text { lower }\end{array}$ & \\
\hline $5.0-5.9$ & Grade 5 and 6 & Grades 5 and 6 & $\begin{array}{c}\text { Medication } \\
\text { Guides, }{ }^{\mathrm{b}} \\
\text { Package } \\
\text { Leaflets }^{\mathrm{c}}\end{array}$ \\
\hline $6.0-6.9$ & Grade 7 and 8 & $\begin{array}{l}\text { Grade } 1-2 \text { in } \\
\text { Junor high } \\
\text { school }\end{array}$ & \\
\hline $7.0-7.9$ & Grade 9 and 10 & $\begin{array}{c}\text { Grade } 3 \text { in } \\
\text { Junior high } \\
\text { school, grade } 1 \\
\text { in high school }\end{array}$ & \\
\hline $8.0-8.9$ & Grade 11 and 12 & $\begin{array}{l}\text { Grades } 2 \text { and } 3 \\
\text { in high school }\end{array}$ & $\begin{array}{l}\text { Drug Guides } \\
\text { for Partients }\end{array}$ \\
\hline $9.0-9.9$ & $\begin{array}{l}\text { Grade } 13 \text { and } 15 \\
\text { (College) }\end{array}$ & College & \\
\hline $\begin{array}{l}10 \text { and } \\
\text { above }\end{array}$ & $\begin{array}{c}\text { Grade } 16 \text { and } \\
\text { higher (College } \\
\text { Graduate) }\end{array}$ & $\begin{array}{l}\text { College } \\
\text { Graduate }\end{array}$ & \\
\hline
\end{tabular}

a The school year in Japan is showed for a reference. ${ }^{b}$ Medication Guides are paper handouts that come with many prescription medicines. The guides address issues that are specific to particular drugs and drug classes, and they contain FDA-approved information that can help patients avoid serious adverse events. ${ }^{\mathrm{c}}$ Package leaflet provides users with information about the medicinal product and its correct use. The package leaflets processed as part of the EU centralised marketing authorisation procedure are published by the European Medicines Agency. ${ }^{d}$ Drug Guides for Partients are primarily used to help patients understand prescription drugs and to help with early detection of serious side effects. Drug Guides for Partients are developed by pharmaceutical companies and published by Ministry of Health, Labour and Welfare.

対象としたユーザーテストの実施が要求される. ユーザーテストに求めるものとして，次のことが挙 げられる.

・信頼のおけるエビデンスを示す.

・ キーとなる安全性メッセージを確定する.

・このようなメッセージをきちんと見つけられ

る.

・ 情報を見つけ，適切に行動できる.

ユーザーテスト実施の詳細については，薬学雑誌 に掲載されているのでそちらを参照されたい. ${ }^{18)}$ ま た，患者向け添付文書である「患者向医薬品ガイ ド19)を用いて，筆者らが国内で初めて実施したユー ザーテストの結果においても，情報の理解度や入手 し易さを評価する上で有用であることが判明し た. ${ }^{20)}$

4-2. 可読性（Readability）＼cjkstart可読性は文章の 
読み易さのことで，文章そのものの表現や用字・用 語を整理統一することで読み易くすることが可能で ある．可読性が良好であるためには，(1)正確に速く 読めること, (2)理解し易いこと, (3)疲労を感じない こと，が挙げられる．日本語には可読性の指標は整 備されていないが，英語では，多音節の語数を数え る Simplified Measure of Gobbledygook (SMOG), そのほか，音節数に文の長さを加えたパラメータを 用いる Fry Readability Scale, Flesch-Kincaid Reading Grade Level, Dale-Chall readability formula など がある. ${ }^{21)}$ Dale-Chall readability formula は，第 4 学年以上の教材を評価する指標で，そのグレードを Table 2 に示す. Dale-Chall readability formula は 英語でのスケールであるが，日本での学年を参考の ため付記した。情報資材のスコアが 5.0-5.9 の第 56 学年相当レベルが望ましいとされているが，実際 にはスコアが 6.0-6.9 の第 9-10 学年相当レベルの 資材が一般には多い。公的な患者向け医薬品情報で ある米国の Medication Guides 及び EU の Package Leaflets は第 5-6 学年相当レベルとしているのに対 し，国内の患者向医薬品ガイドは高校生レベルの理 解力を求めている.

なお，readabilityのほか，視覚的な読み易さに関 するレジビィティ (legibility) というのがあり，こ れにより書体や字詰や行間の工夫で読み易くなる.

\section{5. 最後に}

リスク・ベネフィトコミュニケーションの推進に 向けての課題は多いが, リスクコミュニケーション の有用性を科学的に検証することは，今後ますます 重要になってくると思われる.

現在，「患者及び医療関係者に向けた医薬品等の リスク最小化情報の伝達方法に関する研究」班で は，患者向けコミュニケーションツールのリスク最 小化向けた情報の評価や普及にフォーカスを当て, 研究を推進している．今年度中に，患者・消費者に 向けたリスク情報資材などの作成に関する指針や患 者向け添付文書情報である「患者向医薬品ガイド」 の可読性指針, 患者向医薬品ガイドの理解度調査 （ユーザーテスト）のプロトコル案，「患者向医薬品 ガイド」の提供の改善に向けた情報システムを策定 し提案する予定である.

今後, 医療関係者・患者間での “Shared Decision Making”また “Shared Responsibility”に向け
たリスク・ベネフィットコミュニケーションの環境 整備が進むことを期待したい.

謝辞本シンポジウムの一部は，国立研究開発 法人日本医療研究開発機構 医薬品等規制調和・評 価研究事業「患者及び医療関係者に向けた医薬品等 のリスク最小化情報の伝達方法に関する研究」（研 究代表者 山本美智子）の助成を受けて行われたも のである.

利益相反＼cjkstart開示すべき利益相反はない.

\section{REFERENCES}

1) Fischhoff B., Kadvany J., "Risk: A Very Short Introduction," Oxford University Press, Oxford, 2011.

2) The Royal Society, "The Public Understanding of Science, Report of a Royal Society ad hoc Group endorsed by the Council of the Royal Society," 1985: 〈https://royalsociety. org/ /media/Royal_Society_Content/policy /publications/1985/10700.pdf $\rangle$, cited 31 July, 2017.

3) Organisation for Economic Co-operation and Development (OECD), Public Understanding of Science and Technology, 2001: 〈http:// www.oecd.org/sti/sci-tech/publicunderstand ingofscienceandtechnology.htm $\rangle$, cited 31 July, 2017.

4) Elwyn G., Edwards A., Thompson R., "Shared Decision Making in Health Care: Achieving Evidence-Based Patient Choice," 2nd ed., Oxford University Press, Oxford, 2016.

5) Yamamoto M., Nakaoka S., Nakayama T., Jpn. J. Pharmacoepidemiol., 13, 79-94 (2008).

6) Yamamoto M., Horiki W., Sugimori H., Nakayama T., Jpn. J. Pharmacoepidemiol., 15, 11-21 (2010).

7) WHO Upssala Monitoring Center Glossary of pharmacovigilance terms: 〈https://www.whoumc.org / global-pharmacovigilance / globalpharmacovigilance/glossary/ $/$, cited 31 July, 2017.

8) Morgan M. G., Fischhoff B., Bostrom A., Atman C. J., "Risk Communication: A Mental 
Models Approach," Cambridge University Press, Cambridge, 2001.

9) Effective Communications in Pharmacovigilance-Erice Declaration: 〈http://who-umc. org/graphics/24752.pdf $\rangle$, cited 31 July, 2017.

10) U.S. Food and Drug Administration (FDA), FDA's Strategic Plan for Risk Communication, Fall 2009: 〈https://www.fda.gov/down loads / AboutFDA / ReportsManualsForms / Reports/UCM183683.pdf $\rangle$, cited 31 July, 2017.

11) U.S. Food and Drug Administration (FDA), FDA's Strategic Plan for Risk Communication, Fall 2009, Japanese Version: 〈http:// www.jspe.jp / publication / img / 2010-07-fda. pdf $\rangle$, Japanese Society for Pharmacoepidemiology Web, cited 31 July, 2017.

12) U.S. Food and Drug Administration (FDA), "Communicating Risks and Benefits: An Evidence-Based User's Guide,” 〈https:// www.fda.gov/downloads/AboutFDA/Reports ManualsForms / Reports / UCM268069.pdf $>$, cited 31 July, 2017.

13) President Clinton's memorandum on Plain Language in Government Writing Memorandum for the heads of executive departments and agencies, 1998: 〈http://www.plainlan guage.gov / whatisPL / govmandates / memo. $\mathrm{cfm}\rangle$, cited 31 July, 2017.

14) Plain Writing Act of 2010: 〈https://www.
gpo.gov/fdsys/pkg/CRPT-111hrpt432/pdf / CRPT-111hrpt432.pdf $\rangle$, cited 31 July, 2017.

15) National Cancer Institute (NCI): "Making Health Communication Programs Work (Pink Book)": 〈http://www.cancer.gov/publi cations / health-communication $\rangle$, cited 31 July, 2017.

16) National Institutes of Health (NIH), Clear Communication, Clear \& Simple: 〈https:// www.nih.gov/institutes-nih/nih-office-director/ office-communications-public-liaison / clearcommunication/clear-simple $\rangle$, cited 31 July, 2017.

17) Centers for Disease Control and Prevention $(\mathrm{CDC})$, Clear Communication Index (CCI): $\langle$ http://www.cdc.gov/ccindex $\rangle$, cited 31 July, 2017.

18) Yamamoto M., Doi H., Furukawa A., Yakugaku Zasshi, 135, 277-284 (2015) .

19) Yamamoto M., Matsuda T., Suka M., Furukawa A., Igarashi T., Sugimori H., Jpn. J. Soc. Pharm., 32, 8-17 (2013).

20) Yamamoto M., Doi H., Yamamoto K., Watanabe K., Sato T., Suka M., Nakayama T., Sugimori H., Drug Healthc. Patient Saf., 9, 39-63 (2017).

21) Dale-Chall readability formula: $\langle\mathrm{http}: / / \mathrm{www}$. readabilityformulas.com / new-dale-chall-read ability-formula.php $\rangle$, cited 31 July, 2017. 